\title{
DOMESTIKASI DAN EVALUASI TINGKAT KEMATANGAN GONAD IKAN TILAN MERAH (M astacembelus erytrotaenia)
}

\author{
Sudarto \\ Balai Riset Budidaya Ikan Hias \\ Jl. Perikanan No. 13, Pancoran Mas, Depok \\ E-mail: bukembar@yahoo.com
}

\begin{abstract}
ABSTRAK
Ikan tilan merah merupakan salah satu jenis ikan hias yang sampai saat ini belum dibudidayakan. Potensi sebagai ikan hias dan ikan konsumsi sangat bagus. Untuk itu, dilakukan pembudidayaan di luar habitatnya dengan memelihara calon induk sebanyak 150 ekor di dalam wadah bak beton masing-masing 75 ekor untuk melakukan adaptasi terhadap pakan buatan dan pakan alami berupa cacing tanah selama 2 bulan. Setelah itu dilakukan pengamatan di dalam bak fiberglass ukuran $60 \mathrm{~cm}$ $x 70 \mathrm{~cm} \times 80 \mathrm{~cm}$ (volume air $250 \mathrm{~L}$ ) dengan sistem resirkulasi tertutup. Setiap bak diisi 15 ekor ikan dan dibagi ke dalam 3 perlakuan dengan 3 ulangan, tiap perlakuan diulang 3 kali. Perlakuan pertama diberi pakan buatan $100 \%$ perlakuan kedua diberikan pakan alami (cacing tanah) 100\% dan perlakuan ketiga diberikan 50\%pakan buatan dan 50\%pakan alami. Sampling pertumbuhan dilakukan setiap bulan selama 6 bulan. Kualitas air dilakukan setiap minggu meliputi $\mathrm{O}_{2}$, alkalinitas, $\mathrm{pH}, \mathrm{CO}_{2}$, nitrat, nitrit, amonia, konduktivitas. Pada akhir penelitian dilakukan pembedahan untuk melihat perkembangan gonad. Hasilnya menunjukkan bahwa ikan dengan bobot kurang dari $250 \mathrm{~g}$ mempunyai variasi perkembangan gonad dengan TKG III hingga V, sedangkan bobot di atas $250 \mathrm{~g}$ sudah dijumpai gonad pada TKG VI.
\end{abstract}

KATAKUNCl: Sungai Musi, tilan merah, domestikasi

\section{PENDAHULUAN}

Ikan tilan merah (Mastacembelus erythrotaenia) merupakan salah satu jenis ikan hias air tawar yang ditangkap dari alam di daerah Sumatera terutama di bagian dataran rendah (dekat muara) Sungai Musi, Sungai Batanghari. Badannya sangat panjang bisa mencapai ukuran $100 \mathrm{~cm}$, dengan ekor pipih datar dan barisan duri kecil sepanjang punggung di depan jari-jari sirip punggung, tidak memiliki sirip perut. Moncongnya memanjang membentuk hidung mancung dan lubang hidungnya terletak di samping lubang hidung memiliki 2 tonjolan halus kecil seperti jari dan pinggiran dua bintil putih pipih berdasar; 33-40 duri sirip punggung; 68-85 jarijari pada sirip punggung dan sirip dubur (Kottelat et al., 1995). Terdapat pita warna merah di kepala (berwarna kuning atau putih kalau mati), jari-jari sirip ekor 14-15, bersambung dengan sirip punggung dan sirip dubur.

Hilangnya sejumlah spesies lokal menjadikan keanekaragaman hayati menjadi kecil dan musnahnya spesies tertentu dari alamnya akan mengakibatkan dampak serius untuk lingkungan ekologis (trofic level) maupun aspek biologisnya. Hilangnya satu spesies bisa berakibat hilangnya spesies pemangsanya, ini akan berlanjut ke atasnya, sehingga hilangnya 1 spesies bisa berakibat hilangnya beberapa spesies secara tidak langsung. Selain itu, dampak hilangnya hutan akan memperkecil habitat ikan di alam yang bisa juga memusnahkannya. Ada beberapa spesies ikan air tawar yang diindikasikan punah misalnya ikan balashark (Jambi dan Kalimantan Barat).

Di Sumatera dan Kalimantan Barat ada beberapa spesies ikan tilan antara lain M astacembelus erythrotaenia (tilan merah), Mastacembelus maculatus, Mastacembelus notophthalmus, Mastacembelus unicolor, Macrognatus aculeatus, dan M astacembelusarmatus (Kottelat et al., 1995; Roberts, 1989). Tilan merah adalah jenis tilan yang dikategorikan sebagai ikan hias (Paysan, 1975), yang berukuran paling besar di antara jenis-jenis tilan, berwarna kemerah-merahan, mempunyai sebaran dari Thailand, Kamboja hingga Indonesia; banyak diekspor ke Eropa dan Jepang. Tetapi akhir-akhir ini ikan ini sulit didapat karena diduga dieksploitasi secara besar-besaran baik sebagai ikan hias maupun sebagai ikan konsumsi tanpa dilakukan upaya domestikasi maupun restorasi. Untuk itu, perlu dilakukan pengamatan ekologi di mana ikan yang mempunyai nilai ekonomis tinggi itu berada, Ialu mengambil sampel untuk dilakukan koleksi hidup sebagai bahan studi lanjutan untuk selanjutnya dilakukan 
proses domestikasi dengan melakukan pemeliharaan diberbagai tempat pembesaran guna keperluan penelitian lebih lanjut. Dan juga perlu dilakukan pengamatan perkembangan gonad di alam yang akan dipakai sebagai acuan untuk studi lebih lanjut. Oleh karena itu, pada masa datang perlu dilakukan penelitian yang terkait dengan studi genetika populasi ikan tilan di wilayah ini yang datanya dapat dipakai untuk menunjang keberhasilan studi pengembangbiakannya di luar habitatnya (ex situ) secara terkontrol di hatcheri seperti yang dilakukan terhadap ikan lele (Sudarto, 2003) dan ikan patin (Gustiano, 2003).

Ikan tilan merah (Gambar 1), hidup di perairan yang tenang (demersal) air tawar dengan vegetasi yang lebat atau pada lumpur yang lunak di mana mereka menunggu mangsanya. Suhu air $24^{\circ} \mathrm{C}-32^{\circ} \mathrm{C}, \mathrm{pH} 6-8$. Makanannya berupa ikan atau serangga, cacing, kepiting rawa, dan bagian tanaman. Untuk kebutuhan penelitian maka ikan perlu domestikasi dengan pemeliharaan di luar habitatnya seperti yang dilakukan terhadap ikan balashark (Subandiyah et al., 1995) serta pengamatan gonadnya. Satyani et al. (2002) telah berhasil melakukan pengamatan kematangan gonad dengan pemeliharaan di luar habitat terhadap ikan balashark, dan cara ini juga akan dikaji untuk ikan tilan merah.

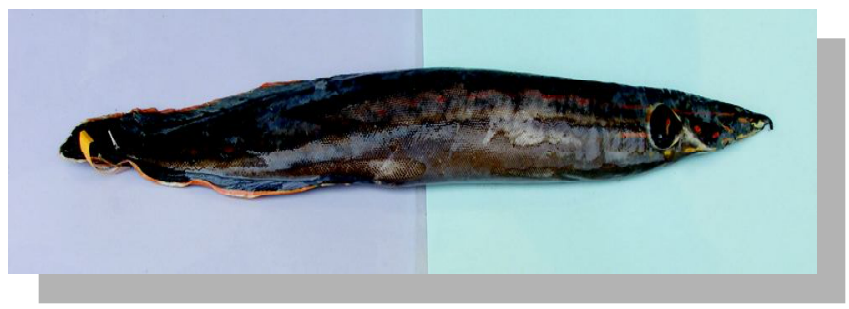

Gambar 1. Calon induk ikan tilan merah, $45 \mathrm{~cm}$ PT

Sistematikan (taksonomi) ikan tilan merah adalah sebagai berikut:

- Domain

: Eukaryota Whittaker \& Margulis, 1978 - eukaryotes

- Kingdom

- Subkingdom

: Animalia Linnaeus, 1758 - animals

- Branch

- Infrakingdom Bilateria (Hatschek, 1888) CavalierSmith, 1983 - bilaterians

Deuterostomia Grobben, 1908 deuterostomes

Chordonia (Haeckel, 1874) CavalierSmith, 1998

- Phylum

: Chordata Bateson, 1885 - chordates

- Subphylum

: Vertebrata Cuvier, 1812 - vertebrates

- Infraphylum : Gnathostomata auct. - jawed vertebrates
- Superclass

- Series

- Class

- Order

- Family

- Genus

- Specific name

- Scientific name : Mastacembelus erythrotaenia Bleeker, 1850

\section{Sinonim:}

1. Macrognathus erythrotaenia (Bleeker, 1850)

2. Mastacembelus argus Günther, 1861

Nama Inggris/nama dagang: Spiny Eels, fire eel, spotted fire eel.

\section{DESKRIPSI}

Badannya sangat panjang dengan ekor pipih datar dan barisan duri kecil sepanjang punggung di depan jari-jari sirip punggung. Panjang maksimum mencapai $100 \mathrm{~cm}$. Tidak memiliki sirip perut. Moncongnya memanjang membentuk hidung mancung dan lubang hidungnya terletak di samping lubang hidung memiliki 2 tonjolan halus kecil seperti jari dan pinggiran dua bintil putih pipih berdasar; 33-40 duri sirip punggung; 68-85 jarijari pada sirip punggung dan sirip dubur. Terdapat pita warna merah di kepala (berwarna kuning atau putih kalau mati), jari-jari sirip ekor 14-15, bersambung dengan sirip punggung dan sirip dubur. Makanannya serangga, kepiting, udang, dan lain-lain. (Gambar 2).

Dari pengamatan ini diharapkan akan mendapatkan calon induk yang terdomestikasi untuk pengembangbiakan lebih lanjut di dalam wadah terkontrol (hatcheri).

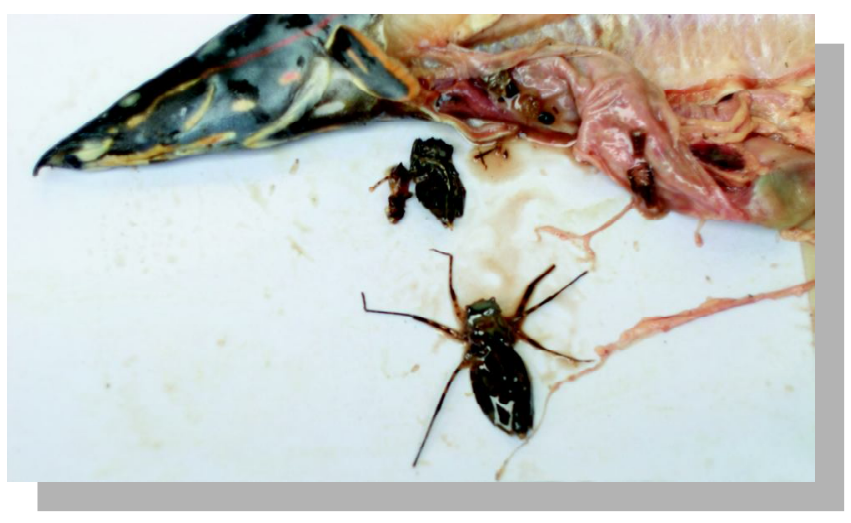

Gambar 2. Isi usus ikan tilan merah terdiri atas Iarva serangga capung dan serangga air lainnya 


\section{KOLEKSI}

Sampel didapat dari pedagang pengumpul di Sumatera Selatan (Palembang) yang mendapatkannya dari nelayan. Ikan hidup dikirim dengan pesawat udara dan transportasi darat dengan waktu tempuh 12 jam hingga tiba di Balai Riset Budidaya Ikan Hias, Depok. Jumlah sample yang diambil 150 ekor sampel hidup dipelihara di dalam wadah terkontrol untuk diamati perkembangan gonad dan pertumbuhannya serta percobaan pemijahannya.

Sebelum dilakukan penelitian maka dilakukan pengamatan lapang di mana ditangkap ikan tilan merah yaitu di Sumatera Selatan. Sedangkan kegiatan pengamatan dilaksanakan dalam wadah berupa bak fiber dengan sistem resirkulasi tertutup (closed system), di Balai Riset Budidaya Ikan Hias.

Domestikasi koleksi sampel hidup dipelihara di dalam 2 buah bak beton masing-masing diisi 75 ekor calon induk; ukuran bak $2 \mathrm{~m} \times 2 \mathrm{~m}$ dengan kedalaman air $80 \mathrm{~cm}$ dipelihara selama 2 bulan untuk aklimatisasi serta pemberian pakan alami pada bak pertama dan pakan buatan Charoon Phokphand (pelet komersial/pakan udang dengan kadar protein 40\% pada bak kedua. Selanjutnya dilakukan treatment di dalam bak fibre dengan volume $200 \mathrm{~L}$, dengan 3 perlakuan dan 3 ulangan kepadatan 15 ekor/bak. Sebanyak 15 ekor sisa dipelihara untuk cadangan jika terjadi kematian. Treatment pakan dengan memberikan pakan dengan pakan alami berupa cacing tanah $100 \%$ pelet udang $100 \%$ (kadar protein $40 \%$, dan campuran $50 \%$ cacing tanah dan 50\%pelet udang; sebesar 5\%bobot total ikan. Kematangan gonad diamati secara kualitatif dengan mengamati perkembangan badan induk jantan dan betina setiap bulan.

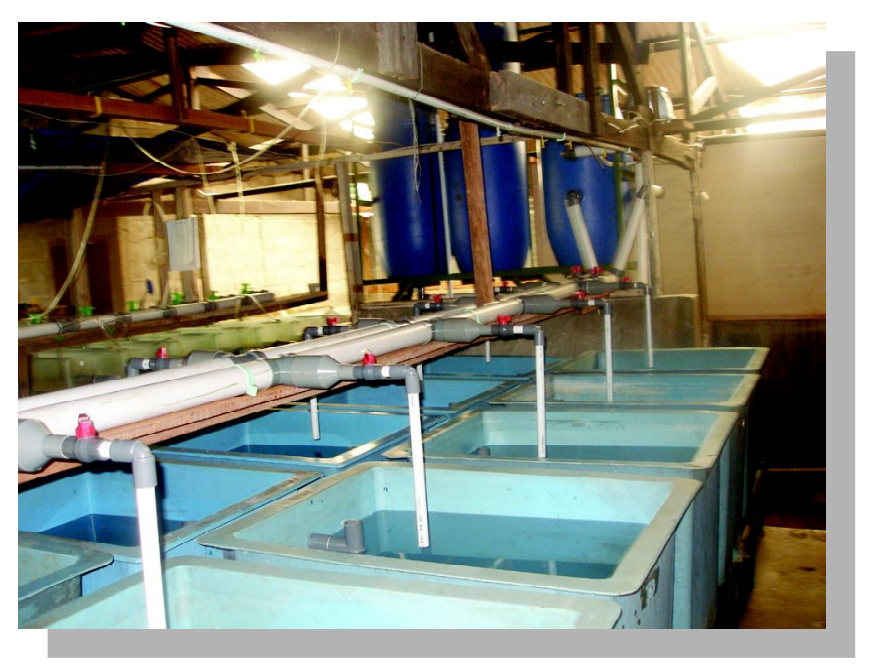

Gambar 3. Wadah pemeliharaan ikan tilan merah di dalam sistem resirkulasi tertutup
Selain itu, dilakukan pengamatan kualitas air setiap minggu untuk mengetahui kondisi lingkungan pemeliharaan. Pemeliharaan di dalam sistem resirkulasi tertutup seperti terlihat pada Gambar 3.

\section{PENGAMATAN PERTUMBUHAN}

Pengamatan pertumbuhan dengan mengukur laju pertumbuhan setiap bulan menunjukkan bahwa pemberian $100 \%$ pakan buatan bobot badan tidak memperlihatkan pertambahan yang nyata; hal ini diduga ikan belum beradaptasi sempurna dengan pakan buatan tersebut. Ikan tidak mengalami pertambahan bobot bahkan cenderung mengalami penurunan. Perlakuan dengan pemberian pakan buatan 50\%dan pakan alami 50\%sedikit mengalami pertumbuhan karena diduga ikan hanya memakan pakan alami berupa cacing tanah sehingga ketersediaannya tidak mencukupi. Sedangkan perlakuan dengan pemberian pakan alami 100\%dengan cacing tanah menunjukkan hasil yang menggembirakan di mana ikan mengalami pertumbuhan dan adanya perkembangan gonad yang menuju kepada stadia akhir. Ini ditunjukkan dari hasil analisis gonad secara mikrosopis (Gambar 4). Selain itu, untuk membuktikan perkembangan gonad maka sebanyak 10 ekor tiap bak (total 90 ekor) dibunuh untuk pengamatan gonad.

Data pertumbuhan rata-rata yang diamati setiap bulan tertera pada Tabel 1. Data ini memperlihatkan bahwa pemberian pakan alami 100\%menghasilkan pertumbuhan terbaik dibandingkan dengan dua perlakuan lainnya.

Tabel 1. Data pertumbuhan ikan tilan merah dengan pemberian pakan buatan dan pakan alami berupa cacing tanah pada tiap perlakuan

\begin{tabular}{lcc}
\hline \multirow{2}{*}{ Perlakuan } & \multicolumn{2}{c}{ Bobot } \\
\cline { 2 - 3 } & Awal & Akhir \\
\hline Pelet $100 \%$ & $190,45 \pm 3,26$ & $189,63 \pm 5,68$ \\
Pelet $50 \%+$ Cacing tanah $50 \%$ & $191,84 \pm 3,72$ & $199,25 \pm 3,27$ \\
Cacing tanah $100 \%$ & $190,83 \pm 3,81$ & $245,36 \pm 7,62$ \\
\hline
\end{tabular}

Dari Tabel 1 dapat dilihat bahwa pada perlakuan pertama (pakan buatan 100\%) ikan tidak tumbuh, sedangkan pada perlakuan kedua (campuran pakan alami $50 \%$ dan pakan buatan $50 \%$ ada pertumbuhan tetapi tidak lebih baik dari perlakuan ketiga (pakan alami cacing tanah $100 \%$. Pada perlakuan ketiga ini ikan mengalami perkembangan gonad yang cukup baik.

Dari sampel hasil pengamatan pertumbuhan yang dilanjutkan dengan pembedahan sebanyak 10 ekor untuk 


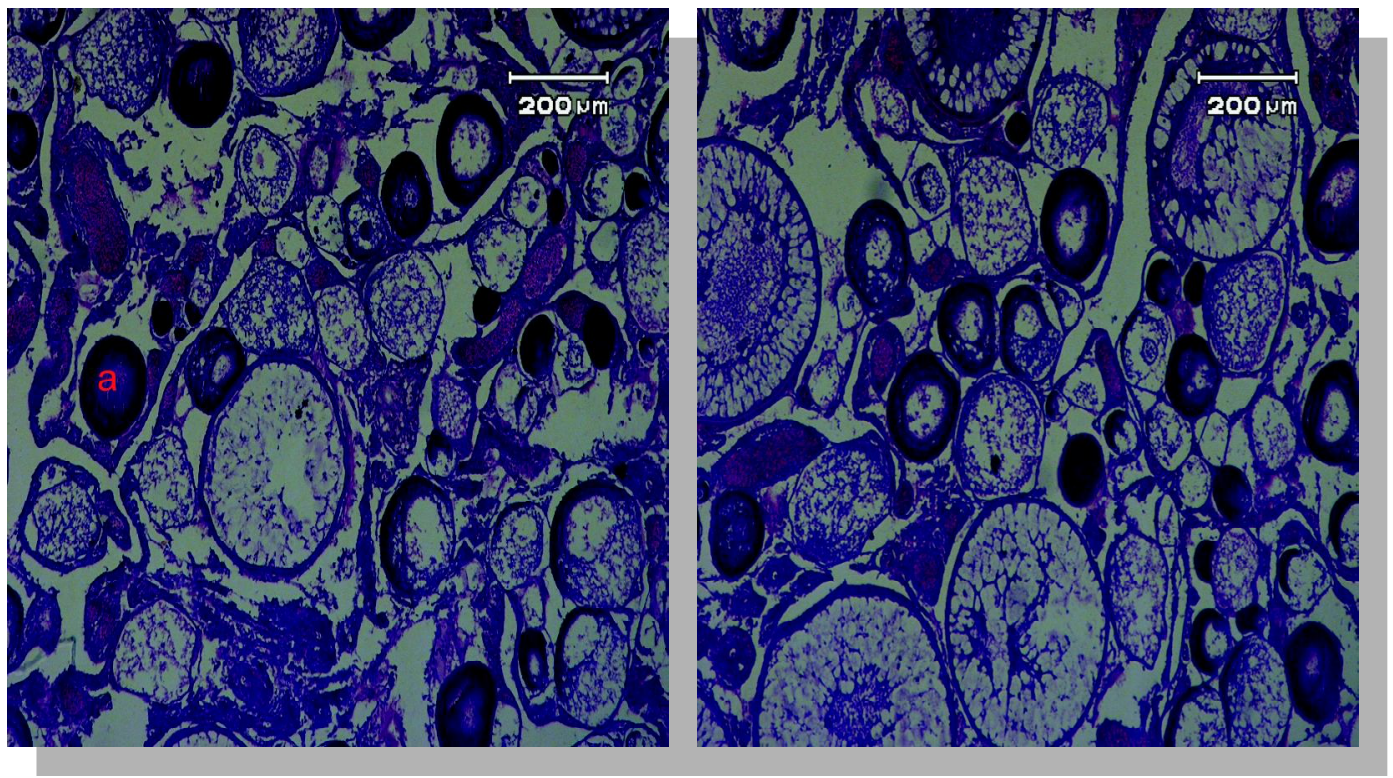

A.B. Fotomikrograf ovarium ikan tilan (TN), menunjukkan oosit (a) (H\&E, 200x)

Gambar 4. Foto mikroskofis perkembangan gonad ikan tilan

setiap wadah maka hasilnya memperkuat asumsi bahwa pakan alami memberikan hasil perkembangan gonad yang terbaik dibandingkan 2 perlakuan lainnya di mana pemberian pakan alami menghasilkan tingkat kematangan gonad (TKG) tertinggi yaitu TKG 6. Gambar 4 menunjukkan perkembangan gonad dengan uji mikroskopis.

Untuk melihat perbedaan kelamin jantan dan betina maka diperlihatkan perbedaan fisik kelamin jantan dan betina pada Gambar 5.

Pengamatan kualitas air yang meliputi suhu, oksigen terlarut, pH, konduktivitas, alkalinitas, nitrat, nitrit menunjukkan hasil yang menunjang kehidupan ikan tilan

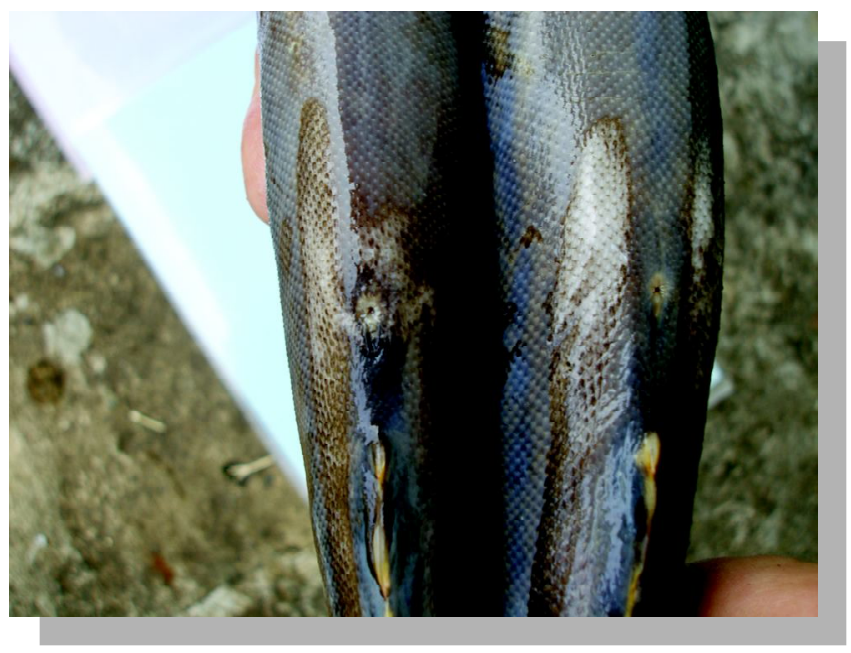

Gambar 5. Perbedaan jantan dan betina ikan tilan merah. Dibandingkan dengan data yang didapat dari sumber lain menunjukkan adanya perbedaan pada nilai konduktivitas yang mempunyai nilai $117 \mu \mathrm{m}$ dan di wadah penelitian bernilai sekitar $310 \mu \mathrm{m}$, hal ini disebabkan kondisi alam di mana ikan tilan berada berbeda dengan kondisi di dalam pemeliharaan terkontrol dengan sistem resirkulasi tertutup. Data kualitas air yang diamati setiap minggu tertera pada Tabel 2.

Tabel 2. Data kualitas air di dalam bak pemeliharaan ikan tilan merah dengan sistem resirkulasi

\begin{tabular}{lc}
\hline \multicolumn{1}{r}{ Parameter } & Kisaran nilai \\
\hline Oksigen $\left(\mathrm{O}_{2}\right)$ & $7,48-7,87$ \\
$\mathrm{pH}$ & $7,57-7,92$ \\
Konduktivitas & $133,3-487,5$ \\
Suhu $\left(^{\circ} \mathrm{C}\right)$ & $26,0-27,3$ \\
Amonia- & $0,02-0,12$ \\
$\mathrm{NH}_{3}-\mathrm{N}$ & $0,000-0,005$ \\
$\mathrm{NH}_{4}{ }^{+}-\mathrm{N}$ & $0,019-0,115$ \\
$\mathrm{NO}_{2}-\mathrm{N}$ & $0,000-0,012$ \\
$\mathrm{NO}_{2}{ }^{-}$ & $0,000-0,039$ \\
\hline
\end{tabular}

Dari Tabel 2 tidak tampak adanya fluktuasi yang signifikan sejak awal hingga akhir penelitian. Tidak pula dijumpai hal-hal yang mengganggu kehidupan ikan seperti penyakit yang berupa bakteri, jamur maupun virus. Hal 
ini dilihat dari nilai kematian yang sangat kecil yaitu hanya 3 ekor dari 135 ekor (2\% ikan terpakai untuk penelitian.

\section{PENUTUP}

Dari hasil pengamatan yang telah dilakukan maka dapat dibuat kesimpulan yaitu ikan tilan merah dapat didomestikasi di luar habitatnya dengan memelihara di dalam wadah dengan sistem resirkulasi tertutup dengan ukuran minimal $250 \mathrm{~g}$ calon induk untuk mendapatkan induk yang siap dipijahkan. Pakan yang terbaik adalah pakan alami berupa 100\%cacing tanah hidup sebanyak 5\% bobot badan.

\section{Saran}

Melakukan penelitian lanjutan dengan calon induk dengan bobot awal $250 \mathrm{~g}$ dengan melakukan stimulasi (perangsangan) perkembangan gonad yaitu dengan melakukan implantasi hormon.

\section{DAFTAR ACUAN}

Gustiano, R. 2003. Taxonomy and phylogeny of Pangasiidae catfishes from Asia (Ostariophysi, Siluriformes). Katholieke Universiteit Leuven Faculty of Sciences Department of Biology, section of ecology and systematics laboratory of comparative anato my and biodiversity B-3000, Leuven, Belgium. Thesis.
Kottelat, M., Whitten, A.J., Kartikasari, S.N., \& Wirjoatmodjo, S. 1995. Freshwater Fishes of Western Indonesia and Sulawesi. Periplus Edition (HK) Ltd. And Ministry of State for Population and Environtment. Rep. of Indonesia, 293 pp.

Paysan, K. 1975. The country life guide to Aquarium Fishes. Country life books, $239 \mathrm{pp}$.

Roberts, T.R. 1989. The freshwater fishes of Western Borneo (Kalimantan Barat, Indonesia). California Academy of Sciences. San Francisco, 210 pp.

Satyani, D., Priyadi, A., Subandiyah, S., Kadarini, T., \& Subagja, J. 2002. Peningkatan keberhasilan kematangan gonad dan ovulasi ikan balashark (Balashark macracanthus). Laporan Hasil Riset Perikanan Air Tawar tahun 2002. Balai Riset Perikanan Budidaya Air Tawar, $6 \mathrm{hlm}$.

Subandiyah, S., Komarudin, O., Yuliati, P., Subagja, J., \& Arianti, F.D. 1995. Penelitian kemampuan penampungan pada air resirkulasi ikan balashark. Prosiding Seminar Hasil Penelitian Perikanan Air Tawar 1993/1994. Balai Penelitian Perikanan Air Tawar, Jakarta, hlm. 82-85.

Sudarto. 2003. Systematic revision and phylogenetic relationships among populations of clariid species in southeast Asia. Thesis. University of Indonesia, Jakarta, $271 \mathrm{hlm}$. 